\title{
Identifikasi Kadar Semen dan Pasir pada Campuran Kering Menggunakan Metode Backpropagation
}

\author{
Gasim*, Sudiadi \\ Program Studi Teknik Informatika \\ STMIK Global Informatika MDP \\ Palembang \\ "gasim@mdp.ac.id
}

\begin{abstract}
Abstrak-Campuran perekat dan juga plesteran dinding pada bangunan biasanya terdiri dari semen dan pasir. Perbedaan kadar campuran semen dan pasir berdampak pada kekuatan hasil. Penelitian ini mengimplementasikan kecerdasan buatan untuk mengidentifikasi atau mengenali kadar campuran semen dan pasir melalui citra campuran semen dan pasir yang sudah kering. Penelitian ini menggunakan enam macam campuran semen dan pasir. Pengumpulan data citra dilakukan dengan cara pemotretan menggunakan kamera resolusi sensor sebesar $7 \mathrm{MP}$, jarak potret lebih kurang $8 \mathrm{~cm}$, dilakukan pada siang hari, dan tidak menggunakan cahaya dari lampu kamera. Citra latih dan citra uji berukuran 500x500 piksel, serta banyaknya citra latih adalah 300 citra dan 150 citra sebagai data uji. Metode pengenalan menggunakan jaringan syaraf tiruan dengan algoritma propagasi balik (backpropagation), dengan input berupa nilai tekstur dari citra campuran semen dan pasir yang sudah kering. Tingkat akurasi keberhasilan identifikasi adalah 87.33\%. Penelitian ini berhasil mengimplementasikan JST dan fitur tekstur analisis dari GLCM dengan jarak potret dan resolusi kamera tertentu, serta penelitian ini dapat menjadi referensi pada penelitian lanjutan.
\end{abstract}

Kata kunci: identifikasi; semen; pasir; tekstur; resolusi sensor; backpropagation

\section{Pendahuluan}

Campuran pasir dalam adukan material bangunan semen merupakan istilah yang terdapat dalam dunia kontruksi. Campuran pasir dalam adukan material bangunan semen tergantung pada fungsinya. Berdasarkan perbedaan fungsi ini, maka komposisi campuran pasir dalam adukan tentunya berbeda pula. Jenis campuran ini antara lain 1) Campuran pasir dengan bahan bangunan semen untuk pasangan bata, 2) Campuran pasir dengan bahan bangunan semen untuk plesteran dinding, 3) Campuran pasir dengan bahan bangunan semen dan batu split untuk beton[1].

Sebuah bangunan akan memiliki perbedaan campuran semen dan pasir pada tiap ruangan. Kamar mandi dan plesteran dinding memiliki komposisi semen dan pasir yang berbeda. Perbandingan semen dan pasir untuk plesteran dinding adalah 1:7-8, dan untuk kamar mandi 1:3-5. Campuran yang keras menggunakan perbandingan semen dan pasir adalah 4:2. Campuran adukan semen dan pasir untuk jalanan adalah 4 rolli pasir, 2 sak semen, dan satu rolli koral [2].

Komposisi adukan dapat diketahui ketika pembuatan adukan material bangunan semen sebelum digunakan. Namun atas alasan tertentu, dibutuhkan informasi tentang berapa kadar semen dan pasir yang terkandung dalam sebuah campuran semen dan pasir yang sudah keras, misalnya hasil plesteran pihak lain, sisa bangunan atau runtuhan bangunan baru atau pun lama. Guna mengetahui kadar campuran semen dan pasir tersebut, biasanya dilakukan uji laboratorium oleh ahlinya.
Adukan semen dan pasir yang sudah mengeras memiliki tekstur. Perbedaan kadar pasir akan mengakibatkan perbedaan tektur. Perbedaan tektur ini sulit dibedakan secara kasat mata, namun perbedaan tektur ini dapat diidentifikasi atau dikenali menggunakan kecerdasan buatan.

Salah satu metode identifikasi atau metode pengenalan yang sering digunakan dalam penelitian adalah Jaringan Syaraf Tiruan (JST), dan input bagi JST tersebut berupa nilai tektur dari citra (foto) adukan yang sudah mengeras (misalnya hasil plesteran dinding).

Metode JST digunakan dalam penelitian klasifikasi mutu pepaya bedasarkan ciri tekstur. Jenis pepaya yang digunakan adalah Calina IPB-9, klasifikasi dilakukan ke dalam tiga kelas mutu yaitu Super, A, dan B. Fitur tekstur yang digunakan adalah energy, entropy, contras, homogeneity, invers difference moment, variance, dan dissimilarity. Hasil pengujian menunjukan fitur energy, dan entropy dapat memberikan tingkat akurasi sebesar $86.11 \%$ [3].

Penelitian terkait perbandingan JST Backpropagation terhadap metode lainya antara lain, perbandingan jaringan learning vector quantization dan backpropagation pada klasifikasi daun. Penelitian ini menghasilkan tingkat akurasi untuk backpropagation sebesar 0,952 sedangkan LVQ adalah 0,420, hal ini menunjukkan bahwa backpropagation lebih baik dari LVQ [4].

Metode pengenalan JST dengan input tekstur analisis sering digunakan pada penelitian identifikasi objek. Di antara penelitian yang menggunakan JST dan tekstur analisis yang menjadi referensi dalam penelitian ini 
adalah identifikasi jenis kayu yang menggunakan metode pengenalan JST dan nilai tekstur analisis sebagai input, penelitian ini mendapatkan tingkat akurasi pengenalan untuk 20 jenis kayu adalah 95\%[5].

Penelitian terkait penggunaan JST telah dilakukan juga terhadap identifikasi serbuk sari, di mana penelitian ini membandingkan kinerja JST terhadap beberapa teknik pengkalasifikasian statistik yang telah diterbitkan sebelumnya, dan hasilnya adalah JST memberikan tingkat keberhasilan lebih tinggi (dalam kasus ini mencapai 100\%) [6].

Jaringan Saraf Tiruan dengan algoritma propagasi balik sebagai metode pengenalan telah digunakan dalam penelitian pengenalan bunga Oxford sebanyak 102 spesies, penelitian ini memberikan tingkat akurasi pengenalan mencapai 81,19\% [7].

Pengenalan tekstur (texture recognition) menggunakan metode pengenalan Artificial Neural Network dan nilai tekstur dari co-occurrence matrix sebagai input, penelitian ini memberikan tingkat akurasi pengenalan atas 13 kelas tekstur adalah $99.3 \%[8]$.

Identifikasi cacat pada tekstil menggunakan metode pengenalan JST dan fitur GLCM sebagai input, penelitian ini memberikan tingkat akurasi keberhasilan identifikasi $91 \%$ s.d. $100 \%[9]$.

Pengenalan tekstur kulit menggunakan metode pengenalan Neural Network dengan nilai input berasal dari GLCM, penelitian ini mendapatkan tingkat akurasi pengenalan $96 \%[10]$.

Diagnosis dini kanker kulit (melanoma) dengan cara klasifikasi gambar dermoscopy berdasarkan nilai GLCM menggunakan metode Multilayer perceptron classifier (MLP) untuk mengklasifikasikan antara Melanocytic Nevi dan Melanoma maligna, penelitian ini memberikan tingkat akurasi 92\%[11].

Penggunaan jaringan syaraf tiruan dengan input tektur analisis dari GLCM juga dilakukan pada penelitian klasifikasi kanker otak melalui citra hasil scan MRI, klasifikasi dilakukan untuk empat tipe kanker otak, yaitu pilocytic, low grade, anaplastic, dan glioblastoma multiforme [12]. Penggunaan JST sebagai metode klasifikasi dan fitur tekstur dari GLCM juga digunakan dalam penelitian klasifikasi sepuluh butir serbuk sari yang berbeda dari spesies tanaman, penelitian ini memberikan tingkat keberhasilan klasifikasi adalah 88\% [13].

Penelitian ini mengimplementasikan Jaringan Syaraf Tiruan (JST) Propagasi Balik (backpropagation), guna melakukan identifikasi beberapa jenis campuran pasir dan semen. Adapun data yang digunakan adalah ekstraksi ciri tekstur analisis dari citra campuran semen dan pasir, di mana citra tersebut diambil dengan jarak pemotretan $8 \mathrm{~cm}$ dan resolusi kamera $7 \mathrm{MP}$.

\section{Metode}

Jalannya penelitian ini dapat digambarkan dalam bentuk bagan seperti disajikan pada Gambar 1.

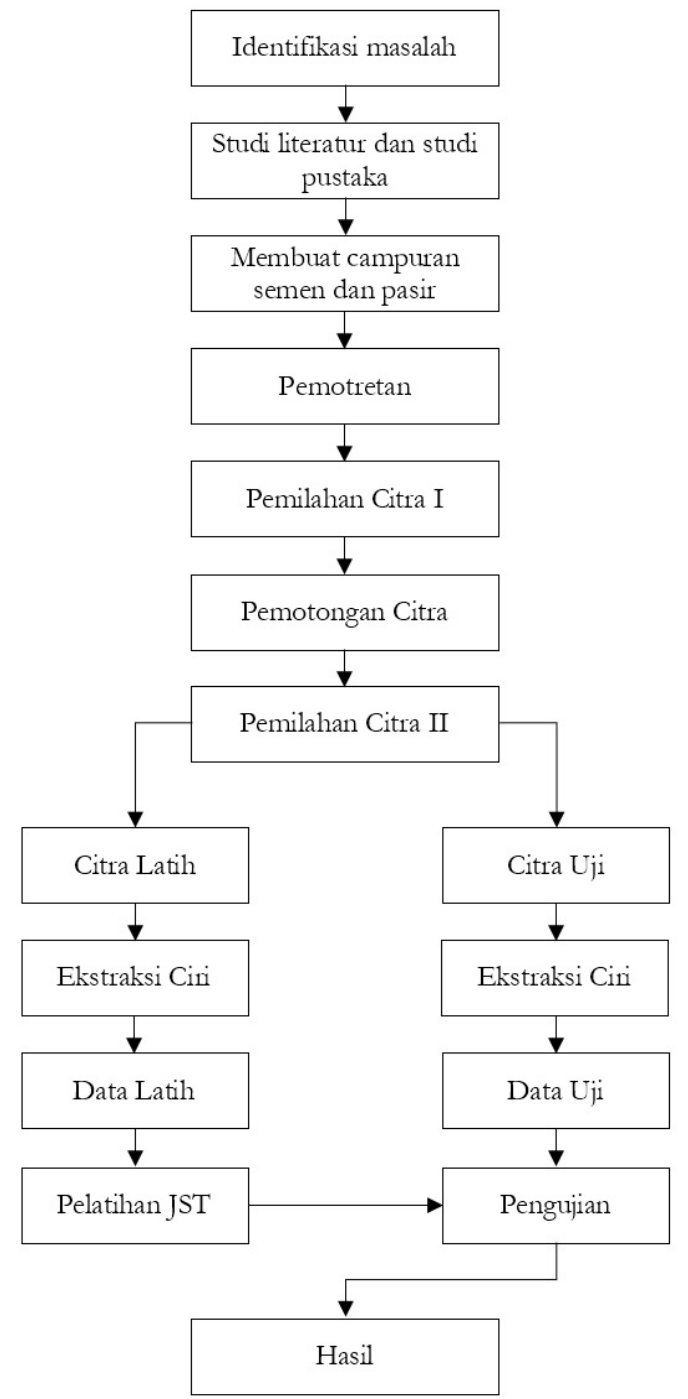

Gambar 1. Langkah kerja peneliltian.

Penelitian ini diawali dengan identifikasi masalah yang akan diselesaikan. Adapun masalah yang diangkat adalah bagaimana menerapkan metode pengenalan JST pada identifikasi kadar semen dan pasir pada campuran yang sudah keras (misalnya hasil pelesateran dinding) menggunakan citra (foto) campuran tersebut. Masalah ini diselesaikan melalui tahapan studi literatur dan pustaka, pengumpulan data yang terdiri dari pembuatan bahan, pemotretan, pemilahan hasil pemotretan, pemotongan citra, pemilihan citra latih dan citra uji, ekstraksi ciri, pelatihan JST, diakhiri dengan pengujian dan hasil.

Studi literatur dilakukan guna mendapatkan referensi terkait penelitian ini. Referensi yang digunakan bersumber dari jurnal nasional maupun internasional terkait objek dan metode yang sudah pernah dilakukan, sehingga tidak terjadi penelitian yang berulang. Studi pustaka dibutuhkan guna mendapatkan teori-teori dasar yang digunakan dalam penelitian ini. 
Pengumpulan data diawali dengan membuat beberapa campuran semen dan pasir yang kemudian dikeraskan (Gambar 2).

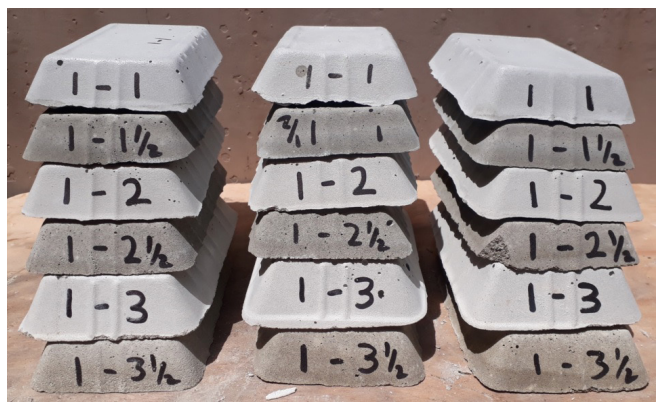

Gambar 2. Sampel campuran semen dan pasir.

Campuran yang dibuat adalah 1 semen 1 pasir, 1 semen 1,5 pasir, 1 semen 2 pasir, 1 semen 2,5 pasir, 1 semen 3 pasir, dan 1 semen 3,5 pasir. Masing-masing campuran dibuat tiga sampel, yaitu dua sampel untuk pelatihan dan satu sampel digunakan untuk pengujian.

Setelah semua sampel tersedia, tahap berikutnya adalah pemotretan. Sebelum pemotretan dilakukan, terlebih dahulu permukaan sampel diratakan dengan cara digosok menggunakan sampel lainnya atau alat lainnya sehingga permukaan rata seperti tampak pada Gambar 3 .

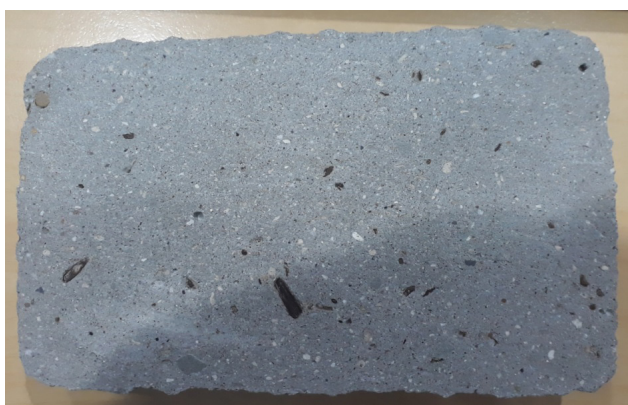

Gambar 3. Permukaan sampel yang sudah diratakan.

Pemotretan dilakukan pada siang hari dengan pencahayaan dari sinar matahari dan tidak menggunakan lampu flash dari kamera. Kamera yang digunakan adalah Canon PowerShot A2200 HD dengan resolusi pemotretan $7 \mathrm{MP}(3072$ x 2304) seperti dapat dilihat pada Gambar 4.

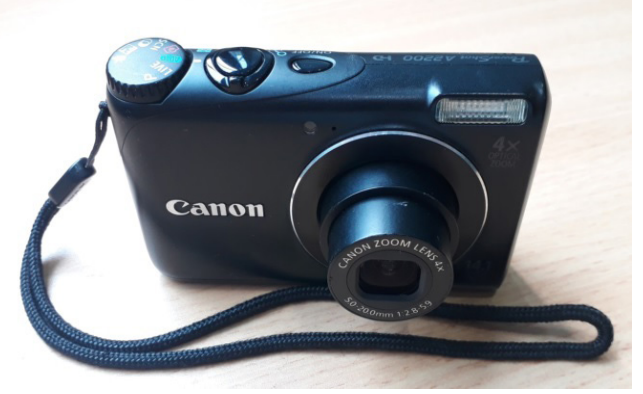

Gambar 4. Kamera yang digunakan.

Pemotretan dilakukan menggunakan jarak lebih kurang $8 \mathrm{~cm}$ (Gambar 5).

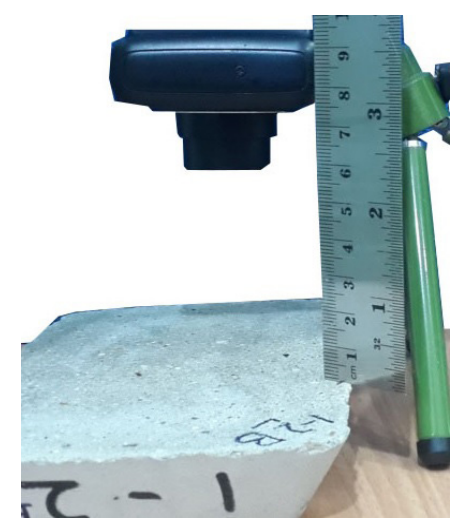

Gambar 5. Kamera yang digunakan.

Pemotrean dilakukan beberapa kali untuk setiap sampel, hal ini dilakukan karena ketajaman (fokus) citra tidak didapatkan pada seluruh bagian citra hasil pemotretan.

Setelah pemotretan dilakukan, selanjutnya seleksi citra hasil pemotretan. Hal ini dilakukan karena tidak semua citra hasil pemotretan merupakan citra yang diharapkan, yaitu citra yang tajam dan tidak kabur (blur).

Selanjutnya pemotongan citra menjadi 500x500 piksel (Gambar 6). Ukuran ini digunakan karena belum ada penelitian sebelumnya yang menguji perbandingan ukuran citra pada identifikasi kadar semen dan pasir pada adukan yang sudah mengeras. Selain itu ukuran 500x500 piksel digunakan mengacu pada penelitian identifikasi jenis kayu yang juga menggunakan objek tektur dan JST [5].

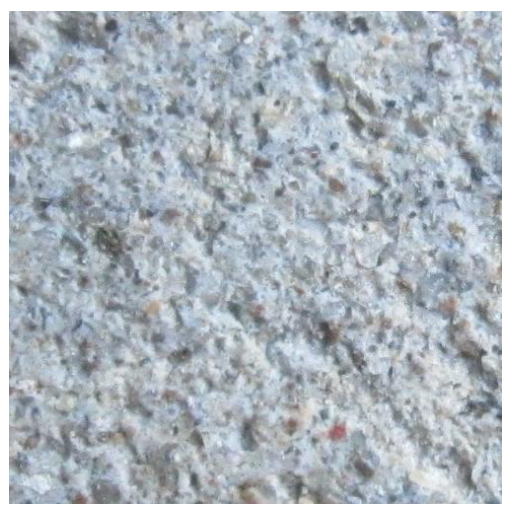

Gambar 6. Citra ukuran 500 x 500 piksel.

Kumpulan citra berukuran 500x500 piksel dipilah lagi untuk mendapatkan citra yang fokus (tidak blur) untuk dijadikan citra latih dan citra uji. Citra latih diambil dari sampel satu dan sampel 2, sedangkan citra uji diambil dari sampel 3. Hal ini dilakukan agar pengujian dilakukan pada sampel yang tidak digunakan pada pelatihan JST. Citra latih yang digunakan sebanyak 50 citra untuk masingmasing jenis campuran, dan citra uji sebanyak 25 citra untuk masing-masing jenis campuran, sehingga total banyaknya citra latih adalah 300 citra latih dan 150 citra uji. Selanjutnya dilakukan ekstraksi ciri terhadap 300 citra latih untuk digunakan sebagai input JST. Adapun ciri yang digunakan adalah entropi (2), standar deviasi (3), kontras (4), homogenitas (5), korelasi (6), energi (7). Proses ini diawali dengan mengubah citra menjadi citra skala keabuan dengan menggunakan rumus (1). 
$\mathrm{f}_{(\mathrm{x}, \mathrm{y})}=0.2989 * \mathrm{R}+0.5870 * \mathrm{G}+0.1140 * \mathrm{~B}$

Entropi

$$
\begin{aligned}
& \text { Entropy } \\
& \text { entropy }=-\sum_{i=0}^{G-1} \sum_{j=0}^{G-1} P(i, j) \times \log (P(i, j))
\end{aligned}
$$

Standar Deviasi

\section{Standard Deviation}

$s t d=\sqrt{\left(\frac{1}{(m \times n)-1}\right)} \sum_{i=1}^{m} \sum_{j=1}^{n}(a[i, j]-\text { mean })^{2}$

Nilai kontras, homogenitas, korelasi, dan energi merupakan nilai tekstur analisis didapatkan dari Gray Level Cooccurrence Matrix (GLCM) [13, 14] yang disajikan pada Gambar 7 [15].

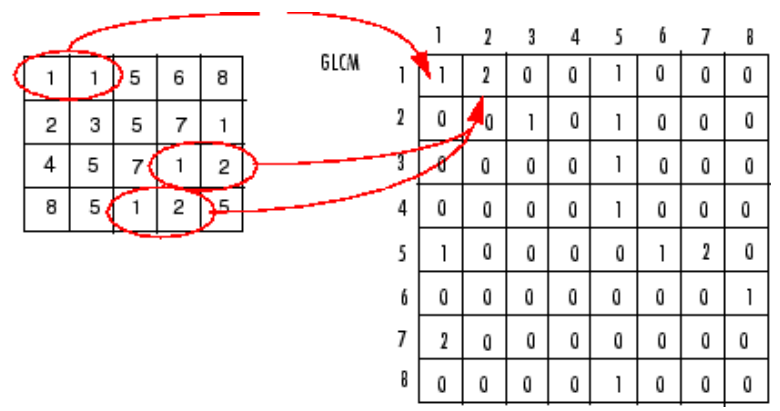

Gambar 7. Proses pembentukan GLCM [15].

Gambar 7 menyajikan proses terbentuknya GLCM dari citra keabuan (gray image). Nilai 1 pada matrik GLCM didapatkan dari matrik citra gray yang hanya ada satu pasang, sedangkan nilai 2 pada matrik GLCM didapatkan dari matrik citra gray yang memiliki dua pasang.

Fitur dari GLCM didapatkan dengan formula kontras (4), homogenitas (5), korelasi (6), energi (7) [14].

Kontras

Contrast

$\sum_{i, j}|i-j|^{2} p(i, j)$

Homogenitas

Homogeneity

$\sum_{i, j} \frac{p(i, j)}{1+|i-j|}$

Korelasi

Correlation

$\sum_{i, j} \frac{(i-\mu i)(j-\mu j) p(i, j)}{\sigma i \sigma j}$

Energi

$$
\sum_{i, j}^{\text {Energy }} p(i, j)^{2}
$$

Proses ekstraksi ini dilakukan menggunakan bahasa pemrograman Matlab sebagai berikut.

citra = '1-3-12.jpg';

ci $=$ imread(citra); $\mathrm{r} 2 \mathrm{~g}=\operatorname{rgb} 2 \mathrm{gray}(\mathrm{ci})$;

en $=$ entropy $(\mathrm{r} 2 \mathrm{~g})$;

std $=\operatorname{std} 2(\mathrm{r} 2 \mathrm{~g})$;

glcm = graycomatrix $(\mathrm{r} 2 \mathrm{~g})$;

chce $=$ graycoprops $($ glcm, $\{$ 'Contrast','Homogeneity','Co rrelation','Energy'\});

Proses ekstraksi ciri akan menghasilkan tabel latih yang terdiri dari enam baris dan 300 kolom. Tiap kolom terdiri dari baris pertama merupakan nilai entropi, baris dua merupakan nilai standar deviasi, baris empat merupakan nilai kontras, baris lima merupakan nilai homogenitas, baris enam merupakan nilai korelasi, dan baris tujuh merupakan nilai energi.

Setelah data latih terbentuk, kemudian membangun dan melatih Jaringan Syaraf Tiruan (JST). Terdapat dua arsitektur JST, yaitu lapis tunggal (Gambar 8) dan lapis banyak (Gambar 9).

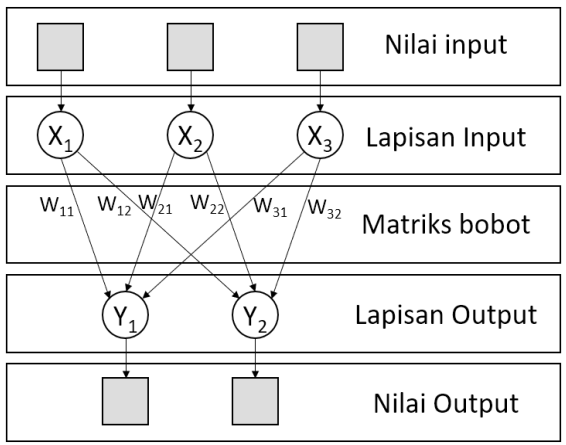

Gambar 8. Model Arsitektur JST lapis tunggal [16].

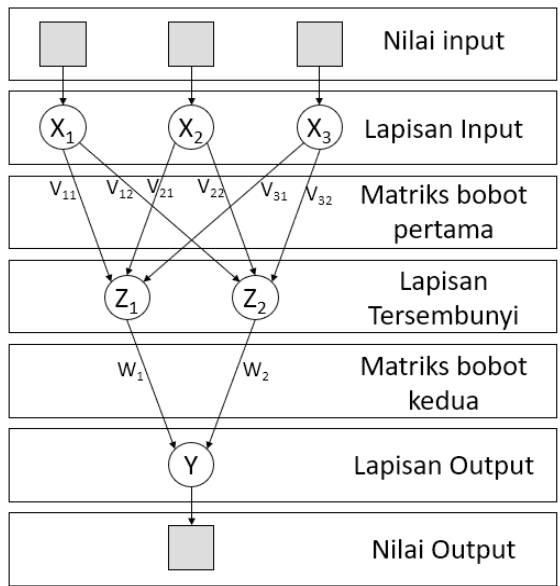

Gambar 9. Model Arsitektur JST lapis jamak [16].

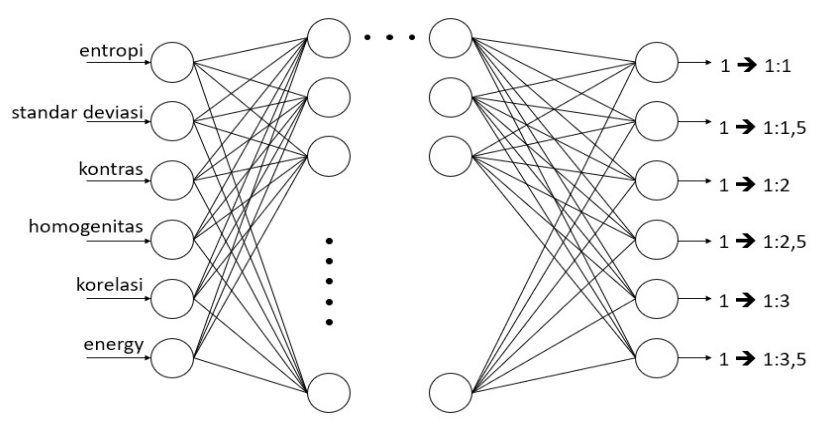

Gambar 10. Contoh nilai hasil ekstraksi ciri. 
Penelitian ini menggunakan model arsitektur JST lapis jamak, dengan arsitektur disajikan pada Gambar 9. Pelatihan JST dimaksudkan supaya semua data latih dapat dikenali oleh JST dengan cara mengubah bobot nilai yang ada dalam JST dengan algoritma propagasi balik.

Gambar 10 menyajikan arsitektur yang digunakan pada proses pelatihan. Terdiri dari enam neuron input, beberapa lapisan tersembunyi (bidden layer), dan enam neuron output.

Pelatihan JST membutuhkan target (nilai output) untuk tiap kolom input dari tabel citra latih. Adapun target yang didefinisikan dalam penelitian ini dapat dilihat pada Tabel 1.

Tabel 1. Definisi target

\begin{tabular}{ccccccc}
\hline Neuron & \multicolumn{7}{c}{ Jenis Camputan } \\
\cline { 2 - 7 } Output & $\mathbf{1 : 1}$ & $\mathbf{1 : 1 . 5}$ & $\mathbf{1 : 2}$ & $\mathbf{1 : 2 . 5}$ & $\mathbf{1 : 3}$ & $\mathbf{1 : 3 . 5}$ \\
\hline Neuron 1 & 1 & 0 & 0 & 0 & 0 & 0 \\
Neuron 2 & 0 & 1 & 0 & 0 & 0 & 0 \\
Neuron 3 & 0 & 0 & 1 & 0 & 0 & 0 \\
Neuron 4 & 0 & 0 & 0 & 1 & 0 & 0 \\
Neuron 5 & 0 & 0 & 0 & 0 & 1 & 0 \\
Neuron 6 & 0 & 0 & 0 & 0 & 0 & 1 \\
\hline
\end{tabular}

Setelah semua citra latih dikenali dalam proses pelatihan, selanjutnya JST tersebut siap digunakan untuk pengujian terhadap citra uji.

Tahap pembentukan data citra uji adalah sama dengan tahapan pembentukan data latih, mulai dari pemotretan hingga ekstraksi ciri. Tahapan tersebut adalah diawali dari pemotretan dilanjutkan dengan pemotongan citra menjadi $500 \times 500$ piksel, kemudian ekstraksi ciri, dan terakhir diujikan pada JST yang sudah melalui tahap pelatihan. Dua tahap terakhir (ekstraksi dan diujikan pada JST) dilakukan menggunakan aplikasi yang turut dikembangkan pada penelitian ini.

\section{Hasil}

\begin{tabular}{|c|c|c|c|c|c|c|c|}
\hline \multicolumn{8}{|c|}{ E Variables - latih50 } \\
\hline \multicolumn{8}{|c|}{ [] latih50 $\times$ L } \\
\hline \multicolumn{8}{|c|}{$\boxplus 6 \times 300$ double } \\
\hline & 1 & 2 & 3 & 4 & 5 & 6 & 7 \\
\hline 1 & 6.6343 & 6.7645 & 6.6608 & 6.6450 & 6.5154 & 6.6160 & 6.4998 \\
\hline 2 & 24.4508 & 26.8108 & 24.7144 & 24.3288 & 22.7758 & 24.3411 & 22.3667 \\
\hline 3 & 0.2792 & 0.3016 & 0.2583 & 0.2741 & 0.2215 & 0.2558 & 0.1963 \\
\hline 4 & 0.8657 & 0.8559 & 0.8746 & 0.8666 & 0.8913 & 0.8756 & 0.9025 \\
\hline 5 & 0.7888 & 0.8054 & 0.8095 & 0.7917 & 0.8083 & 0.8061 & 0.8275 \\
\hline 6 & 0.2274 & 0.1907 & 0.2195 & 0.2130 & 0.2776 & 0.2227 & 0.2716 \\
\hline 7 & & & & & & & \\
\hline
\end{tabular}

Gambar 11. Contoh nilai hasil ekstraksi ciri.

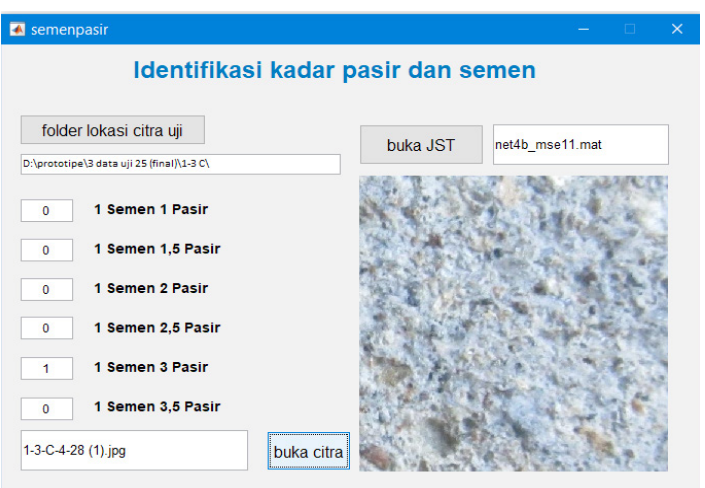

Gambar 12. Aplikasi pengujian.
Ekstaksi ciri citra latih menghasilkan tabel latih (300 kolom $\times 6$ baris) yang digunakan pada proses pelatihan JST. Gambar 11 menunjukkan potongan tabel latih hasil ekstraksi ciri.

Pengujian dilakukan menggunakan aplikasi yang turut dikembangkan pada penelitian ini (Gambar 12). Urutan penggunaan aplikasi ini (Gambar 12) adalah sebagai berikut:

1. Tentukan lokasi citra uji, gunakan tombol folder lokasi citra uji

2. Buka atau load JST yang sudah dilatih, gunakan tombol buka JST

3. Buka atau load citra yang akan diuji, gunakan tombol buka citra

Setelah citra dipilih, maka aplikasi akan langsung mengidentifikasi dan hasilnya ditampilkan dibagian kiri pada enam teks box yang tersusun vertikal, teks box ini memberikan berfungsi memberikan nilai 0 atau 1 , sebagai contoh pada Gambar 12 semua teks box memberikan angka 0 kecuali teks box untuk 1 semen 3 pasir ini berarti bahwa citra yang dibuka adalah citra jenis campuran 1:3.

Hasil pengujian memberikan tingkat akurasi pengenalan mencapai $87 \%$, dengan spesifikasi JST disajikan pada Tabel 2 .

Tabel 2. Spesifikasi JST

\begin{tabular}{ll}
\hline \multicolumn{1}{c}{ Komponen } & \multicolumn{1}{c}{$\mathbf{1 : 1}$} \\
\hline Asitektur & 3 hiddn layer \\
Algoritma & Propagasi balik \\
Neuron hidden layer & $49,39,47$ \\
Neuron input layer & 6 (entropi, standar deviasi, kontras, \\
homogenitas, korelasi, energy) & 6 (jenis campuran) \\
Neuron output layer & $1 \mathrm{e}-11$ \\
MSE & 300 \\
Total data latih & 150 \\
$\begin{array}{l}\text { Total data uji } \\
\text { Akurasi penganalan } \\
\text { data latih }\end{array}$ & $100 \%$ \\
$\begin{array}{l}\text { Akurasi penganalan } \\
\text { data uji }\end{array}$ & $87 \%$ \\
\hline
\end{tabular}

Gambar 13 menunjukkan proses training (pelatihan) JST yang terdiri dari 3 lapisan tersembunyi (bidden layer). Pelatihan ini mampu mencapai target 1e-11, hal ini dapat dilihat pada bagian Performance dan juga dibuktikan pergerakannya pada Gambar 14, dan banyaknya epoch yang dibutuhkan adalah 2838 iterasi, hal ini dapat dilihat pada Gambar 14 bagian Epoch.

Gambar 14 menunjukkan pergerakan MSE dalam mencapai goal yang ditetapkan yaitu 1e-11. Nilai ini digunakan karena pada posisi 1e-11 sudah menunjukkan semua data latih sudah dapat dikenali (dapat dilihat pada Gambar 15), dan pada posisi 1e-11 menunjukkan nilai terbanyak dari data uji yang dapat dikenali atau diidentifikasi.

Gambar 15 merupakan proses pelatihan yang menunjukkan bahwa semua data latih dapat dikenali dengan tepat, hal ini dapat dilihat pada bahwa semua data sudah berkumpul pada pojok kanan atas dan nilai $\mathrm{R}$ sudah mencapai 1. 


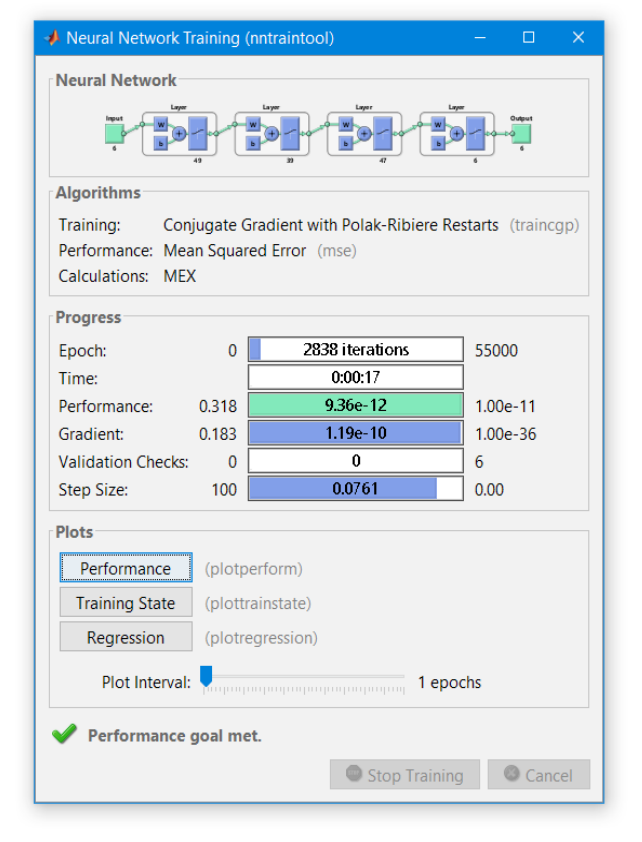

Gambar 13. Proses training JST.

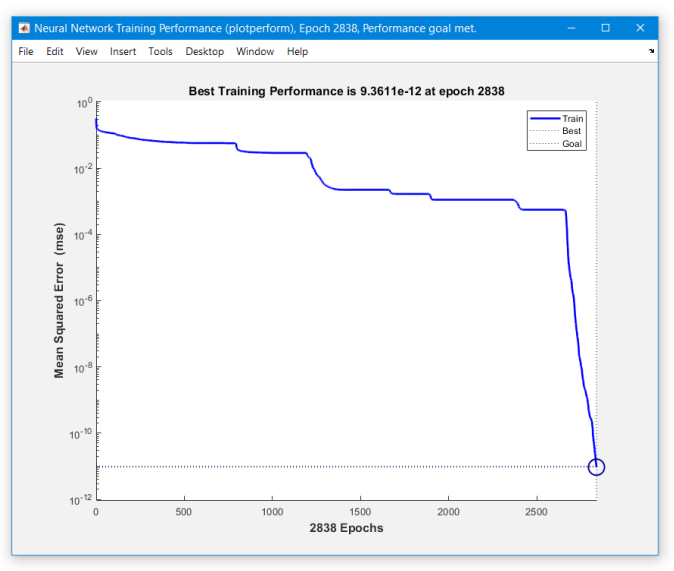

Gambar 14. Proses pergerakan MSE.

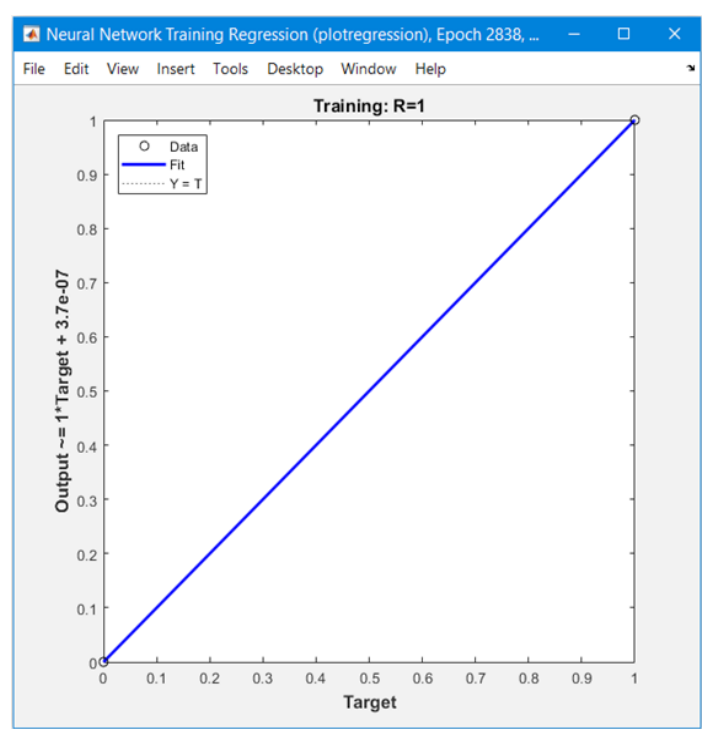

Hasil akhir pelatihan.
Tabel 3 menunjukkan detail dari pengujian terhadap enam jenis campuran semen dan pasir.

Tabel 3. Detail hasil pengujian

\begin{tabular}{cccc}
\hline $\begin{array}{c}\text { Jenis } \\
\text { campuran }\end{array}$ & $\begin{array}{c}\text { Jumlah } \\
\text { data uji }\end{array}$ & Dikenali & $\begin{array}{c}\text { Tidak } \\
\text { dikenali }\end{array}$ \\
\hline $1: 1$ & 25 & 25 & 0 \\
$1: 1.5$ & 25 & 25 & 0 \\
$1: 2$ & 25 & 9 & 16 \\
$1: 2.5$ & 25 & 25 & 0 \\
$1: 3$ & 25 & 22 & 3 \\
$1: 3.5$ & 25 & 25 & 0 \\
Total & 150 & 131 & 19
\end{tabular}

Tabel 3 menunjukkan bahwa jenis campuran 1:1 , 1:1.5 , 1:2.5 dan 1:3.5 mampu dikenali untuk semua data uji yaitu sebanyak 25 data uji. Jenis campuran 1:2 hanya mampu dikenali sebanyak 9 buah dari 25 data uji. Sedangkan jenis campuran 1:3 mampu dikenali sebanyak 22 buah dari 25 data uji. Sehingga secara keseluruhan terdapat 131 data uji yang mampu di dikenali dari 150 data uji $(87,33 \%)$.

\section{Kesimpulan}

Selaras dengan beberapa penelitian sejenis [3-13] yang memadukan penggunakan fitur tekstur analisis dengan JST mampu memberikan tingkat akurasi keberhasilan mulai dari 80\% hingga 100\%. Penelitian ini membuktikan bahwa pengenalan atau identifikasi kadar campuran semen dan pasir dapat dilakukan dengan menggunakan kecerdasan buatan (JST) berbasiskan citra, hal ini dapat dilihat dari hasil pengujian yang disajikan pada Tabel 3 yang mampu memberikan tingkat akurasi pengenalan hingga 87,33\%.

Campuran 1 semen 2 pasir (1:2) memiliki akurasi pengenalan terendah, salah satu penyebanya adalah dikarenakan campuran ini memiliki nilai-nilai fitur yang dekat dengan nilai-nilai fitur pada campuran 1:2.5, sehingga terjadi salah identifikasi.

Beberapa hal yang belum dilakukan pada penelitian sebelumnya, sehingga keputusan penggunaanya belum memiliki landasan yang kuat, misalnya penggunaan jarak potret yang hanya berdasarkan jarak terdekat yang mampu ditangkap oleh kamera yang digunakan, dan juga belum ada penelitian yang membandingkan tingkat akurasi berdasarkan jarak potret dan juga resolusi kamera.

Penggunaan ukuran citra bukan berdasarkan objek yang sama. Hal ini dilakukan karena belum ada penelitian dengan objek yang sama yang melakukan perbandingan tingkat akurasi pengenalan berdasarkan ukuran citra. Bahkan belum ada penelitian yang secara khusus membahas tentang teknik pemotretan untuk masalah identifikasi ini.

Perlu adanya penelitian lanjutan guna menguji metode yang terdapat pada pengumpulan data, misalnya jarak potret, tingkat resolusi kamera, pencahayaan, ukuran citra. 


\section{Daftar Pustaka}

[1] Indocement Corporation, "Mengenal Jenis-jenis Campuran Pasir dalam Adukan Bahan Bangunan Semen", semen tiga roda, 30 Mei 2015, [Online]. Tersedia: bttps: / / wnw.sementigaroda.com/ read/ 20150730/170/mengenal-jenis-jenis-campuran-pasirdalam-adukan-bahan-bangunan-semen, [Diakses: 16 April 2019]

[2] Bawaan Situs, "6 Kesalahan Ketika Membuat Adukan Semen”, lyceum, 28 Feb 2017, [Online]. Tersedia: https:// www.lyceum.id/6-kesalaban-ketikamembuat-adukan-semen, [Diakses: 15 Mei 2019]

[3] Wibowo F, Harjoko A, “ Klasifikasi Mutu Pepaya Berdasarkan Ciri Tekstur GLCM Menggunakan Jaringan Saraf Tiruan", Khazanah Informatika. vol. 3, no. 2, pp. 100-104, 2017.

[4] S.Adinugroho, Y.A.Sari, "Perbandingan Jaringan Learning Vector Quantization dan Backpropagation pada Klasifikasi Daun Berbasiskan Fitur Gabungan", Jurnal Informatika \& Multimedia, Vol.9, No.2, pp.58-64, 2017.

[5] Gasim, Harjoko A, Seminar K.B., Hartati S., "Image Blocks Model for Improving Accuracy in Identification Systems of Wood Type," (IJACS A) International Journal of Advanced Computer Science and Applications., vol. 4, no. 6, pp. 48-53, 2013.

[6] P. Li, dan J.R. Flenly, "Pollen texture identification using neural networks", Grana, Vol. 38, pp. 59-64, 1999

[7] A. Huthaifa, M. Saher, H.Hazem, "A Flower Recognition System Based On Image Processing And Neural Networks", International Journal of Scientific \& Technology Research, Vol.7, no. 11, pp.166-173, 2018

[8] H.S.A. Suhair, E.G. Loay, "Texture Recognition Using Co-Occurrence Matrix Features and
Neural Network," Journal of Theoretical and Applied Information Technology., vol. 95, no.21, pp. 59495961, 2017

[9] G. Azim, "Identification of Textile Defects Based on GLCM and Neural Networks," Journal of Computer and Communications, vol. 3, no. 12,pp. 1-8, 2015.

[10] K.A.Nidhal, S.D. Nizar, A.A. Zaid, "Skin Texture Recognition Using Neural Networks," Conference: ACIT 2008, vol. 9, 2009.

[11] S.M. Mai, A.S. Mariam,S. Amr, "Automatic Detection of Melanoma Skin Cancer using Texture Analysis,". International Journal of Computer Applications., vol. 42, no. 20, pp. 22-26, 2012.

[12] S. Jain, "Brain Cancer Classification Using GLCM Based Feature Extraction in Artificial Neural Network", International Journal of Computer Science \& Engineering Technology (IJCSET)., vol.4, no. 7, pp. 966-970, 2013.

[13] Y.Kaya, M.E.Erez, O.Karabacak, L.Kayci, M.Fidan,"An automatic identification method for the comparison of plant and honey pollen based on GLCM texture features and artificial neural network", Grana, Vol. 52, no. 1, pp.71-77, 2013. DOI: $10.1080 / 00173134.2012 .754050$

[14] R.M. Haralick, K. Shanmugam, I. Dinstein, "Textural Features for Image Classification," IEEE Transaction On System, Man and Cybernetics, vol. 3, no. 6, pp. 610-621, 1973.

[15] Mathworks Corporation, "Create a Gray-Level Co-Occurrence Matrix", MATLAB for Artificial Intelligence, 2019, [Online]. Tersedia: bttps:// www.mathworks.com/ help/images/create-a-gray-level-cooccurrence-matrix.html, [Diakses:16 April 2019].

[16] Sutojo T, Mulyanto E, dan Vincent, 2010. Kecerdasan Buatan. Yogyakarta: Andi Offset. 